\title{
Mealtime assistance and identification of eating difficulties prevent unintended weight loss in nursing home residents - A controlled trial
}

\author{
Preben Ulrich Pedersen, Kirsi Kuosma, Yrsa Andersen Hundrup \\ Department of Health Science Technology, Aalborg University, Denmark
}

Correspondence: Preben Ulrich Pedersen. Address: Department of Health Science Technology, Aalborg University, Denmark. Email: pup@hst.aau.dk

Received: July 23, 2014

Accepted: August 21, 2014

Online Published: September 1, 2014

DOI : 10.5430/jnep.v4n11p33

URL: http://dx.doi.org/10.5430/jnep.v4n11p33

\begin{abstract}
Background: The study evaluated an individualized multifactorial intervention to enhance the nutritional intake in nursing home residents.

Method: The study was carried out as a controlled intervention study. Baseline data was collected during the first month and the intervention was continued for twelve months. Five units participated. Three units were conveniently selected for intervention and the two units as control units. Residents were included consecutively during the study period. In total 163 residents were available. Nutritional risk, eating difficulties and weight were obtained at baseline and every 3 months for a year.
\end{abstract}

Interventions: An individual care plan was developed for each resident receiving extra mealtime assistance.

Results: Rresidents who received mealtime assistance increased the average body weight significantly whereas the residents in the control units decreased their weight.

Conclusion: Systematic identification of eating difficulties combined with sustained mealtime assistance is a safe and effective method to maintain body weight in nursing home residents.

\section{Key words}

Malnutrition, Nursing home, Care plans, Weight loss, MNA, Mealtime assistance, Eating difficulties, Individualized care

\section{I ntroduction}

The prevalence of European nursing home residents at risk of malnutrition being malnourished has been found to be $35 \%$ $-70 \%{ }^{[1-4]}$. Malnutrition, low body mass index (BMI) and unintentional weight loss are risk factors for mortality and have a negative influence on the functional status and psychosocial well-being ${ }^{[5,6]}$. The risk of developing pressure ulcers ${ }^{[7]}$ and infections is increased ${ }^{[8]}$ and symptoms like fatigue and confusion (or disorientation) may also be caused by poor nutritional intake ${ }^{[10]}$. Good nutritional status and prevention of weight loss due to malnutrition is important to prevent frailty in elderly ${ }^{[6,11]}$. 


\subsection{Factors associated with malnutrition}

Elderly people in general consume smaller meals and fewer snacks between meals, and they eat more slowly than younger ${ }^{[16]}$. Furthermore, gastrointestinal problems, mental disorders, depression and use of medicine are associated with low dietary intake ${ }^{[12-14]}$. Other factors such as poor appetite and eating alone increase the risk of low food intake and unintentional weight loss ${ }^{[1,14,15]}$.

Moreover, the senses of smell and taste seems to decline and so does the pleasantness of the taste of the meal often resulting in a loss of appetite and a less varied food intake ${ }^{[17,18]}$. The inability to feed oneself for various reasons is a major risk factor of malnutrition ${ }^{[16,19]}$. However, in most residential homes meals are concentrated to the hours during the day, and this may in itself cause malnutrition among the residents. In Danish nursing homes staffing is often reduced significantly after $3 \mathrm{pm}^{[20,21]}$. This increases the risk for prolonging the so-called night fasting ${ }^{[20]}$. If the night fasting becomes too long, the body starts breaking down muscle to access energy, which in turn can lead to weight loss and muscle weakness ${ }^{[20]}$. Staff might overlook residents at risk for malnutrition as screening for malnutrition is a neglected area in nursing homes ${ }^{[1]}$.

\subsection{I ncreasing nutritional intake}

One of the major sources of pleasure in the elderly is the taste of food and therefore, it is a challenge to the health care providers to stimulate this enjoyment for as long as possible ${ }^{[12]}$.

Few controlled studies have evaluated interventions that intend to increase nutritional intake and reduce unintentional weight loss in nursing home residents. Nutritional supplementation might cause positive outcomes in elderly especially in hospital settings ${ }^{[22-25]}$. In nursing homes nutrition supplements has been described as the least likely method to enhance energy intake in subjects with low body weight ${ }^{[24]}$. These findings have been supported by a Cochrane review that concluded that intervention with oral supplementation may not be suited to elderly people with long term reduction of food intake $^{[25]}$.

An individualised approach that focuses on a stimulating mealtime environment combined with systematic nutritional assessment and relevant mealtime assistance and feeding support has been suggested to improve the quality of life and prevent the decline in physical performance and weight loss in elderly people and nursing home residents ${ }^{[11,26,27]}$. Feeding assistance was effective to increase nutritional intake among $90 \%$ of nursing home residents ${ }^{[28]}$. Participants significantly increased their daily food intake either in response to face-to-face mealtime assistance or to snacks served between meals. It was noted that more staff was necessary to effectively implement the two types of interventions.

Nutritional intake in old people is affected by many factors and a strategy build on individualized care plans describing multifactorial interventions, systematic assessment of nutritional risk factors and supervision of staff ${ }^{[11]}$ might prevent unintended weight loss. This is supported by a comprehensive review that identifies at least 37 factors that affect the nutritional intake in older adults ${ }^{[29]}$.

Our study attempts to implement and evaluate an individualized multifactorial intervention to enhance the nutritional intake in nursing home residents in the everyday routines in a nursing home. The purpose was to identify residents with the highest risk of weight loss and to evaluate the effectiveness of individual care plans and increased meal time support during the day, afternoon and evening hours combined with the serving of nutritional enriched food and snacks between meals in order to prevent weight loss.

\section{Methods}

The study was carried out as a controlled intervention study in a large public nursing home in Copenhagen. Baseline data was collected during the first month and the intervention was by October $1^{\text {st }}$ and continued to the end of September next 
year. The nursing home provides housing for 360 residents. The study was carried out in five units, each of which had separate rooms for 25 residents. Three of the units were conveniently selected for intervention and the two units acted as control units. Residents were included consecutively during the study period. All residents that were living in one of the five units were included in the study from the start and if a resident died the new resident participated. In total 163 residents were available for this study.

All residents had there nutritional risk assessed using the Short Form of the Mini Nutritional Assessment (MNA-SF), were screened for eating difficulties and had their weight measured at baseline and every 3 months during the study period. Residents residing in the control units received usual care and residents living in the intervention units were eligible for extra personal mealtime assistance if they met three or more of the following criteria:

- $\quad$ MNA- SF - score of 7 points or below

- $\quad \mathrm{BMI}<20$

- An unintentional weight loss of $>3 \mathrm{~kg}$ between two weighing

- The presence of severe eating difficulties, i.e. swallowing or chewing problems

All together 24 residents were assigned extra mealtime support during the study period. An individual care plan for the activities to be provided by the mealtime assistants was developed for each resident, and the plan was adjusted on the basis of the daily reports from the staff and mealtime assistants.

Although overweight and obesity may be an increasing problem among nursing home residents ${ }^{[30]}$, residents with a BMI of $\geq 28 \mathrm{~kg} / \mathrm{m}^{2}$ were excluded in this study. This was done, as our aim was to prevent unintended weight loss in residents, and was anticipated that obese residents intentionally could lose weight.

\subsection{Measurement of nutritional status}

MNA-SF was used to identify residents at risk of malnutrition as it is developed for and validated on elderly people ${ }^{[2]}$. MNA-SF has proved to retain good diagnostic accuracy ${ }^{[31]}$. MNA-SF in Danish has been used it in an earlier study, where it proved easy to administer ${ }^{[11]}$. The MNA-SF adds up to a maximum score of 14 points. A score of 11 points or below indicates risk of malnutrition.

In MNA-SF the following areas are assessed (see Table 1); Has food intake declined over the past three months due to loss of appetite, digestive problems, chewing or swallowing difficulties? Involuntary weight loss during the last three months? Mobility? Has the resident suffered psychological stress or disease the last three months? Neuropsychological problems? In our study severe dementia was recorded if the residents were unable to express themselves about their physical, social or psychological needs. Mild dementia was recorded, if the resident showed interest in taking care of their toilet needs and was able to express themselves about other kinds of needs. No psychological problems were recorded if the residents were alert and able to communicate and to take care of themselves.

\subsection{Nutritional intervention}

A care plan for each of the included residents was developed, identifying:

- The type of snacks between meals preferred by the resident. Preferred favourable dishes, and serving these whenever possible

- $\quad$ Preferred protein and energy enriched food between meals 
- Preferred physical activity, for instance taking the resident for a walk either outdoor or indoor or a drive in a wheelchair before a meal.

The care plan was available for all staff. On a daily basis (except Sundays) extra mealtime assistance was available from 4 p.m. to 8 p.m. The mealtime assistants were recruited among students from different health professions. They had a two day course focusing on nourishment of old people, appetite stimulation, availability of enriched food and snacks and received continuous supervision by the same nurse (local project leader - KK). Communication with demented people was trained. The mealtime assistant was responsible for making an individualised written care plan that encompassed information on how to:

- create a pleasant and quiet atmosphere during the meal

- avoid interruption during the meal by protecting the residents from distracting factors

- avoid social isolation by encouraging the resident to eat the meals together with others

- $\quad$ assist the resident for as long as it took to eat the meal.

\subsection{Data collection}

The weighing of the residents took place in the morning before residents were dressed. The same digital sitting scale on each unit was used to measure the body weight, and the weight was measured to the nearest $0.1 \mathrm{~kg}$. The same weight was used to the same resident at each weighing. Body mass index (BMI) was calculated by dividing the weight in kilo by the height in $\mathrm{m}^{2}$.

\subsection{Statistical analysis}

Data were processed by means of the statistics programme Statistical Package for Social Sciences (SPSS). The results are given as means $\pm 1 \mathrm{SD}$. Student's paired and unpaired two-tailed $t$-test was used, if data were normally distributed. Mann-Whitney rank sum test was used if data were not normally distributed. To test for significance between normal- or ordinal-level data, the chi-square test $\left(\chi^{2}\right)$ or the Mann-Whitney test was used. To obtain confidence limits we used statistic tables. $P$-values below 0.05 were considered significant.

\subsection{Ethical considerations}

It was voluntary to participate in the study, and if a resident refused to be weighed, this was fully respected. Privacy and anonymity was protected throughout the study. The study was assessed by the Scientific Ethical Committees of The Capital Region of Denmark, which concluded that this type of study focusing on the quality of care did not include an obligation to obtain a written consent from the residents (H-B-2007-102).

\section{Results}

Of the 163 residents $19(12 \%)$ were excluded due to $\mathrm{BMI}<28 \mathrm{~kg} / \mathrm{m}^{2}$. Of the remaining 144 residents 89 residents resided in the intervention units and 55 in the control units. No differences were found among residents in the intervention and the control units except for swallowing problems $(p=.017)$ (see Table $1 \& 2)$.

During the study period 33 residents died, and 34 new residents were successively included in the study. Ninety-four residents (65.3\%) had their body weight measured at least four times (see Table 3). 
Table 1. Baseline characteristic of residents in the intervention units and control units

\begin{tabular}{|c|c|c|c|}
\hline Baseline characteristics & Intervention $\mathbf{N}=\mathbf{8 9}$ & Controls $N=55$ & $p^{*}$ \\
\hline Mean age in years $(\mathrm{SD})$ & $83.3( \pm 10.9)$ & $85.6( \pm 8.8)$ & $.283^{\dagger}$ \\
\hline \multicolumn{4}{|l|}{ Gender } \\
\hline Female & $64(71.9 \%)$ & $42(76.4 \%)$ & \multirow{2}{*}{$.693^{\dagger \dagger}$} \\
\hline Male & $25(28.1 \%)$ & $13(23.6 \%)$ & \\
\hline Mean BMI $\left(\mathrm{kg} / \mathrm{m}^{2}\right)$ & $21.3( \pm 3.4)$ & $21.9( \pm 2.8)$ & $.275^{\dagger}$ \\
\hline \multicolumn{4}{|l|}{ Anthropometric measures } \\
\hline Weight (kg) mean (SD) & $56.4( \pm 11.5)$ & $56.4( \pm 8.8)$ & \multirow{3}{*}{$\begin{array}{l}.971^{\dagger} \\
.239^{\dagger} \\
.275^{\dagger}\end{array}$} \\
\hline Height (cm) mean (SD) & $162( \pm 11.0)$ & $160( \pm 10.2)$ & \\
\hline Mean BMI kg/m² mean (SD) & $21.2( \pm 3.4)$ & $21.8( \pm 2.8)$ & \\
\hline \multicolumn{4}{|l|}{ BMI categories * } \\
\hline $\mathrm{BMI}<19$ & $22(25.9 \%)$ & $10(18.9 \%)$ & \multirow{4}{*}{$.275^{\dagger \dagger \dagger}$} \\
\hline BMI 19-20.9 & $14(16.5 \%)$ & $10(18.9 \%)$ & \\
\hline BMI 21-22.9 & $17(20.0 \%)$ & $13(24.5 \%)$ & \\
\hline $\mathrm{BMI} \geq 23($ number $\& \%)$ & $32(37.6 \%)$ & $20(37.7 \%)$ & \\
\hline \multicolumn{4}{|l|}{ MNA -screening } \\
\hline$\geq 12$ point & $6(5.7 \%)$ & $3(7.1 \%)$ & \multirow{2}{*}{$1.000^{\dagger \dagger}$} \\
\hline$\leq 11$ point & $79(94.3 \%)$ & $50(92.9 \%)$ & \\
\hline \multicolumn{4}{|l|}{ Loss of appetite within latest 3 months } \\
\hline Severe loss of appetite & $15(16.9 \%)$ & $3(5.5 \%)$ & \multirow{3}{*}{$.065^{\dagger \dagger \dagger}$} \\
\hline Mild loss of appetite & $11(12.4 \%)$ & $12(21.8 \%)$ & \\
\hline No loss of appetite & $63(70.8 \%)$ & $40(72.7 \%)$ & \\
\hline \multicolumn{4}{|l|}{ Mobility } \\
\hline Bed or chair bound & $38(42.7 \%)$ & $17(30.9 \%)$ & \multirow{3}{*}{.313} \\
\hline Able to get out of bed/chair, but does not get out & $32(36.0 \%)$ & $26(47.3 \%)$ & \\
\hline Goes out & $19(21.3 \%)$ & $12(21.8 \%)$ & \\
\hline \multicolumn{4}{|l|}{ Psychological stress or acute disease } \\
\hline Yes & $54(60.7 \%)$ & $37(67.3 \%)$ & \multirow{2}{*}{$.479^{\dagger \dagger}$} \\
\hline No & $35(39.3 \%)$ & $18(32.7 \%)$ & \\
\hline \multicolumn{4}{|l|}{ Neuropsychological problems } \\
\hline Severe dementia & $41(46.1 \%)$ & $19(34.5 \%)$ & \multirow{3}{*}{$.313^{\dagger \dagger \dagger}$} \\
\hline Mild dementia & $38(42.7 \%)$ & $29(52.7 \%)$ & \\
\hline No psychological problems & $10(11.2 \%)$ & $7(12.7 \%)$ & \\
\hline
\end{tabular}

*) We were unable to calculate the BMI in six residents, because we were unable to calculate their height.

${ }^{\dagger}$ Student's $t$-test; ${ }^{\dagger \dagger}$ Chi-square test; ${ }^{\dagger \dagger}$ Mann-Whitney test

Table 2. Baseline prevalence of eating problems among 144 nursing home residents in interventions and control units respectively

\begin{tabular}{|c|c|c|c|c|c|}
\hline \multirow{2}{*}{ Eating difficulties } & \multicolumn{2}{|c|}{ Residents in intervention units $n=89$} & \multicolumn{2}{|c|}{ Residents in control units $n=55$} & \multirow{2}{*}{$p^{*}$} \\
\hline & Yes (n) & $\%$ & Yes (n) & $\%$ & \\
\hline Chewing problems & 22 & 24.7 & 12 & 21.8 & .840 \\
\hline Swallowing problems & 15 & 16.9 & 2 & 3.6 & .017 \\
\hline Difficulties tolerating food & 6 & 10.9 & 7 & 7.9 & .561 \\
\hline Difficulties cutting food & 47 & 52.8 & 20 & 36.4 & .061 \\
\hline Difficulties bringing food to the mouth & 17 & 19.1 & 8 & 14.5 & .651 \\
\hline Difficulties using a cup & 22 & 24.7 & 10 & 18.2 & .414 \\
\hline Difficulties using a glass & 20 & 22.5 & 10 & 18.2 & .674 \\
\hline Difficulties using cutlery & 21 & 23.6 & 12 & 21.8 & .841 \\
\hline Unable to remove drinks from refrigerator & 48 & 53.9 & 29 & 52.7 & 1.00 \\
\hline Unable remove food from refrigerator & 48 & 53.9 & 30 & 54.5 & 1.00 \\
\hline
\end{tabular}

\footnotetext{
* Chi-square test
} 
Table 3. The cumulative proportion of residents surviving to have their body weight measured during the study

\begin{tabular}{|c|c|c|c|c|c|c|}
\hline \multirow{3}{*}{ Number of measurements of body weight } & \multicolumn{2}{|c|}{ Intervention units } & \multicolumn{2}{|c|}{ Control units } & \multicolumn{2}{|c|}{ Total } \\
\hline & \multicolumn{2}{|c|}{$\mathrm{N}=89(61.8 \%)$} & \multicolumn{2}{|c|}{$n=55(56.4 \%)$} & \multicolumn{2}{|c|}{$N=144(100 \%)$} \\
\hline & $\mathbf{n}$ & $\%$ & $\mathbf{n}$ & $\%$ & $\mathbf{N}$ & Cum \% \\
\hline Measurement $\times 5$ & 49 & 55.1 & 32 & 58.2 & 81 & 56.3 \\
\hline Measurement $\times 4$ & 8 & 9.0 & 5 & 9.1 & 13 & 65.3 \\
\hline Measurement $\times 3$ & 8 & 9.0 & 6 & 10.9 & 14 & 75.0 \\
\hline Measurement $\times 2$ & 9 & 10.1 & 4 & 7.3 & 13 & 84.0 \\
\hline Measurement $\times 1$ & 13 & 14.6 & 8 & 14.5 & 21 & 98.6 \\
\hline Measurement $\times 0$ & 0 & 0.0 & 2 & 2.2 & 2 & 100.0 \\
\hline
\end{tabular}

Table 4 shows the average weight changes in residents at risk of being malnourished (MNA-SF score $\leq 11$ ). The residents, who resided in the intervention units, increased their average weight with $1.3 \mathrm{~kg}$, whereas the residents in the control units decreased their weight with $0.67 \mathrm{~kg}(p=.035)$.

Comparing weight changes (weight loss $>3$ kilo, weight stability, weight gain $>3$ kilo) we found no statistical significant differences between residents in the intervention and the control units in each of the four study periods. But we found that $20 \%$ (CI 95\%: 10.00-33.7) of the residents in the intervention units versus 36.3\% (CI 95\%:20.6-57.7) in the control units had a weight loss of more than 3 kilo $(p<.05)$.

Table 4. Average weight changes (kilo) among residents at risk of being malnourished (MNA-SF score of $\leq 11$ ) in each of the study periods and in residents, who participated long enough to be have at least 4 consecutive weighing in intervention wards and ontrol wards respectively

\begin{tabular}{|c|c|c|c|c|c|c|c|}
\hline \multirow{2}{*}{ Study periods } & \multicolumn{3}{|c|}{ Intervention } & \multicolumn{3}{|c|}{ Control } & \multirow{2}{*}{${ }^{*} p$} \\
\hline & $\mathbf{N}$ & kg & SD & n & kg & SD & \\
\hline October quarter & 55 & 0.136 & 3.7 & 33 & -0.318 & 2.6 & .545 \\
\hline January quarter & 56 & 0.834 & 3.0 & 36 & 0.389 & 2.4 & .455 \\
\hline April quarter & 53 & 0.464 & 3.2 & 37 & -1.624 & 3.1 & .003 \\
\hline July quarter & 53 & -0.417 & 2.4 & 35 & 0.314 & 2.6 & .186 \\
\hline
\end{tabular}

*Student's $t$-test

Table 5 shows that residents who had mealtime assistance, had significant lower body weight, lower BMI and lower MNA-score compared to the other residents in intervention and control units. Twenty-four residents received mealtime assistance for 8 months (range 3-10). During this period the residents increased the average body weight significantly with $1.273 \mathrm{~kg}$ whereas the residents in the control units decreased their weight with $0.976 \mathrm{~kg}(p=.046)$.

Table 5. Baseline characteristics of residents with mealtime assistance compared to residents without mealtime assistance in intervention units and to residents in control units for residents with Mini Nutritional-SF score of $\leq 11$

\begin{tabular}{|c|c|c|c|c|c|c|c|c|}
\hline \multirow[b]{3}{*}{ Male (\%) } & \multicolumn{5}{|c|}{ Intervention units } & \multicolumn{3}{|c|}{ Control units } \\
\hline & \multicolumn{2}{|c|}{$\begin{array}{l}\text { Residents with mealtime } \\
\text { assistance }(n=24)\end{array}$} & \multicolumn{2}{|c|}{$\begin{array}{l}\text { Residents without mealtime } \\
\text { assistance }(n=55)\end{array}$} & \multirow[t]{2}{*}{$P *$} & \multicolumn{2}{|c|}{$\begin{array}{l}\text { Residents without mealtime } \\
\text { assistance }(n=50)\end{array}$} & \multirow[t]{2}{*}{$\boldsymbol{P} * *$} \\
\hline & 6 & 25.0 & 16 & 29.1 & & 12 & 24.0 & \\
\hline Female $(\%)$ & 18 & 75.0 & 39 & 70.9 & .790 & 38 & 76. & .660 \\
\hline Age years (SD) & 84.6 & 10.4 & 83.5 & 10.2 & .669 & 84.6 & 9.3 & .555 \\
\hline Weight kg (SD) & 50.0 & 8.7 & 58.5 & 11.2 & .002 & 56.1 & 9.2 & .324 \\
\hline BMI kg/m² & 18.5 & 2.4 & 21.7 & 3.1 & .002 & 21.9 & 2.5 & .716 \\
\hline MNA score (SD) & 4.6 & 2.4 & 7.3 & 2.7 & .000 & 7.2 & 2.5 & .797 \\
\hline
\end{tabular}

* Differences between residents with mealtime assistance compared to residents without mealtime assistance in intervention.

** Differences between residents without mealtime assistance in interventions and control wards. 
No significant difference was found between the residents who received mealtime assistance and residents who did not received mealtime assistance in the intervention units (see Table 6).

When we compared weight changes among residents with mealtime assistance we found that fewer had had a weight loss (9.1\%; CI 95\%:1-29.1) compared to the residents without mealtime assistance in the intervention units (21.6\%; CI 95\%:11.2-35.2) and this was statistically significant $(p<.05)$.

Table 6. Average weight changes in residents (Mini Nutritional-SF score of $\leq 11$ ) mealtime assistance (a) compared to residents in the intervention units without mealtime assistance (b) and with the residents in control units (c)

\begin{tabular}{|c|c|c|c|c|c|c|c|c|c|c|c|}
\hline \multirow[t]{2}{*}{ Study periods } & \multicolumn{3}{|c|}{$\begin{array}{l}\text { Residents with mealtime } \\
\text { assistance (a) }\end{array}$} & \multicolumn{4}{|c|}{$\begin{array}{l}\text { Residents without mealtime } \\
\text { assistance (b) }\end{array}$} & \multicolumn{4}{|c|}{$\begin{array}{l}\text { Residents without mealtime assistance } \\
\text { in control units (c) }\end{array}$} \\
\hline & $\mathbf{n}$ & kg & SD & $\mathbf{n}$ & kg & SD & $p$ & $\mathbf{n}$ & kg & SD & $p$ \\
\hline October quarter & 19 & -0.626 & 4.2 & 44 & 0.393 & 3.3 & .308 & 33 & -0.318 & 3.3 & .697 \\
\hline January quarter & 19 & 1.200 & 2.7 & 44 & 0.311 & 3.4 & .321 & 31 & 0.403 & 3.4 & .312 \\
\hline April quarter & 18 & 0.828 & 2.5 & 41 & 0.495 & 3.6 & .722 & 30 & -1.207 & 3.6 & .013 \\
\hline July quarter & 17 & 0.129 & 2.6 & 42 & 0.067 & 2.7 & .310 & 28 & 0.382 & 2.7 & .834 \\
\hline All study periods & 24 & 1.273 & 4.4 & 52 & 0.657 & 4.3 & .578 & 33 & -0.976 & 4.3 & .046 \\
\hline
\end{tabular}

\section{Discussion}

In both intervention and control units the baseline prevalence of residents BMI $<20 \mathrm{~kg} / \mathrm{m}^{2}$ was $40 \%$, which corresponds with findings in earlier studies ${ }^{[1,2,4]}$. Two thirds of all residents had eating difficulties and $40 \%$ had more than four different eating problems, and nine out of ten suffered from neuropsychological problems and of these were $42 \%$ severely demented. Only a very small proportion of the residents were physically or mentally able to move around indoor or outdoor, and almost $40 \%$ of the residents died during the study period. These findings may be explained by the fact that since the 1970's substantial efforts made to avoid institutionalization of older Danish citizens ${ }^{[32]}$. This development has left only those in need of care around the clock to be cared for in nursing homes.

However, in spite of the frailty of the residents we found a small but significant positive effect of the multi-factorial nutritional intervention implemented in this study. Residents in intervention units increased their body weight with 1.086 $\mathrm{kg}$, on average whereas residents in control units decreased their average body weight with $1.298 \mathrm{~kg}$ (see Table 4), and fewer residents in the intervention units had a weight loss than residents in the control units. Several studies have found that older people with dementia are particularly vulnerable to malnutrition ${ }^{[1,34,35]}$ and that eating difficulty related to dementia is a significant predictor of low food intake. When dementia advances the food intake is affected as a result of the damages of the brain, and these damages affect not only ingestion of nutrients or fluids, but also the feeding process itself. This process includes getting the food into the mouth and effective chewing and swallowing mechanisms. Impaired feeding difficulties may lead to inadequate food intake, weight loss, malnutrition and aspiration of food elements ${ }^{[36]}$. In our population we found significant more residents in the intervention units than in the control units that suffered from swallowing difficulties, which could indicate that they suffered from more advanced stages of dementia than residents in the control units, and this may have diluted the effect of the intervention.

In a controlled trial of the effect of feeding assistance to nursing home residents the intervention group gained 0.75 units more in the final BMI and 4.2 pounds $(1.9 \mathrm{~kg})$ more in the final body weight ${ }^{[37]}$. Fifty-six per cent of the participants maintained or gained weight during the intervention phase compared with $28 \%$ in the control phase ${ }^{[37]}$. These findings support our findings showing that sustained optimal feeding assistance can prevent weight loss in residents at risk of weight loss due to inadequate food intake.

We could only show significant weight gain among the residents who received feeding assistance for a considerable length of time. This indicates that it takes a long time to improve the daily food intake to a degree that makes it possible to establish measurable lasting weight stability. 
The nutritional care to those selected for feeding assistance was in most cases provided individually (one-on-one feeding), but in some cases it was possible to assist more than one resident during the meal. Unfortunately we did not systematically record the time spent on each resident, but it is estimated that the support lasted from 30-45 minutes. It might be argued that most Danish nursing homes may not have the necessary staff to provide this meal time support for all residents in need feeding assistance. However, Simons et al. ${ }^{[28,38]}$ have shown that group feeding assistance is as effective as one-to-one care.

Due to limited resources, it was not possible to provide effective mealtime assistance to all residents in need of this support, therefore it should be considered, if this type of care could be provided in a more feasible and less time consuming way.

\section{Strengths and limitations of the study}

The strength of this study was the length of the study lasting altogether a full year, which made it possible to implement this new concept of providing personal mealtime assistance to prevent unintentional weight loss, a process that took almost three months.

We used a simple, but validated instrument to assess risk of malnutrition. It strengthened the internal reliability of the measurements and thereby the validity of the study that all MNA-SF assessments were carried out by the same well-qualified registered nurse (local project leader KK) throughout the study period. It also strengthened the study that the local project leader acted as a supervisor for the mealtime assistants, meaning that immediate actions could be taken in accordance with the screening scores, and the mealtime assistants and the supervisor could evaluate the outcome of these actions on a day-to-day basis.

However, the study may also have a limitation related the assessment of dementia. In an earlier Danish study ${ }^{[32]}$ the Geriatric Mental Schedule (GMS) was used to diagnose psychiatric morbidity. It was assessed that $61 \%$ of the nursing home residents fulfilled the criteria for organic dementia while nine percent suffered from depression. We used the MNA-SF screening tool to rate residents with neuropsychological problems, and therefore we were unable to discriminate between organic dementia and depression. We might have overestimated the prevalence of dementia. On the other hand; the previously Danish findings were based on data from 1995, and since then the general health among nursing home residents have deteriorated.

Before this study was implemented no systematic assessment procedures were carried out neither in the intervention or the control units. The implementation of regularly assessment of the nutritional status including weighing may have improved the nutritional care not just in the intervention units but also in the control units. This problem, known as the Hawthorne effect, may have caused a kind of placebo effect ${ }^{[39]}$. In the present study we might have found a higher effect of the intervention, had this effect not interfered with the results.

\section{Conclusion}

Systematic identification of eating difficulties combined with an individual care plan and sustained mealtime assistance is a safe and effective method to maintain body weight in nursing home residents.

\section{Acknowledgment}

The study was funded by the Ministry of Social Affairs. Journal number 9591-006-01

\section{References}

[1] Geurden B1, Franck Mpsych E, Lopez Hartmann M, Weyler J, Ysebaert D. Prevalence of 'being at risk of malnutrition' and associated factors in adult patients receiving nursing care at home in Belgium. Int J Nurs Pract. 2014 May 9. 
[2] Verbrugghe M1, Beeckman D, Van Hecke A, Vanderwee K, Van Herck K, Clays E, et al. Malnutrition and associated factors in nursing home residents: a cross-sectional, multi-centre study. Clin Nutr. 2013 Jun; 32(3): 438-43. PMid:23089280 http://dx.doi.org/10.1016/j.clnu.2012.09.008

[3] Stange I1, Poeschl K, Stehle P, Sieber CC, Volkert D.Screening for malnutrition in nursing home residents: comparison of different risk markers and their association to functional impairment. J Nutr Health Aging. 2013 Apr; 17(4): $357-63$. PMid:23538659 http://dx.doi.org/10.1007/s12603-013-0021-z

[4] Suominen M, Muurinen S, Routasasalo P, Soini H, Suur-Uski I, Piponen A, et al. Malnutrition and associated factors among aged residents in all nursing homes in Helsinki. Eur J Clin Nutr. 2005; 59: 578-583. PMid:15744328 http://dx.doi.org/10.1038/sj.ejcn.1602111

[5] Beck AM, Pedersen AN, Schroll M. Undervægt og utilsigtet vægttab hos ældre på plejecentre og i hjemmepleje- problemer der bør gøres noget ved [Underweight and unintentional weight loss among elderly in nursing homes and in home care - problems requiring attention]. Ugeskr Læger 2005; 167(3): 272-274. PMid:15704794

[6] de Groot CP, van Staveren WA. Survey in Europe on Nutrition and the Elderly, a Concerted Action. Undernutrition in the European SENECA studies. Clin Geriatr Med. 2002 Nov; 18(4): 699-708. http://dx.doi.org/10.1016/S0749-0690(02)00043-5

[7] Banks M, Bauer J, Graves N, Ash S. Nutrition. 2010; 26: 896-901. PMid:20018484http://dx.doi.org/10.1016/j.nut.2009.09.024

[8] Scrimshaw NS, SanGiovanni JP. Synergism of nutrition, infection, and immunity: an overview. Am J Clin Nutr. 1997; 66: 464S-477S. PMid:9250134

[9] Jeejeebhoy KN. Malnutrition, fatigue, frailty, vulnerability, sarcopenia and cachexia: overlap of clinical features. Curr Opin Clin Nutr Metab Care. 2012; 15(3): 213-9. PMid:22450775 http://dx.doi.org/10.1097/MCO.0b013e328352694f

[10] Lildballe DL, Fedosov S, Sherliker P, Hin H, Clarke R, Nexo E. Association of cognitive impairment with combinations of vitamin $\mathrm{B}_{12}$-related parameters. Clin Chem. 2011; 57(10): 1436-43. PMid:21836078 http://dx.doi.org/10.1373/clinchem.2011.165944

[11] Kuosma K, Hjerrild J, Pedersen PU, HundrupYA. Assessment of the nutritional status among residents in a Danish nursing home - Health effect of a formulated food and meal policy. Journal of Clinical Nursing. 2008; 17: 2288-2293. PMid:18717007 http://dx.doi.org/10.1111/j.1365-2702.2007.02203.x

[12] Berry EM, Marcus EL. Disorders of eating in the elderly. Journal of Adult Development. 2000; 7: 87-99. http://dx.doi.org/10.1023/A:1009575706990

[13] Parker BA, Chapman IM. Food intake and ageing - the role of gut. Mech Ageing Dev. 2004; 125:859-866. PMid:15563931 http://dx.doi.org/10.1016/j.mad.2004.05.006

[14] Shahar D, Shai I, Vardi H, Fraser D. Dietary intake and eating patterns of elderly people in Israel: who is at nutritional risk? Eur J Clin Nutr. 2003; 57: 18-25. PMid:12548292 http://dx.doi.org/10.1038/sj.ejcn.1601523

[15] Hughes G, Bennett KM, Hetherington MM. Old and alone: barriers to healthy eating in older men. Appetite. 2004 ; $43: 269-276$. PMid:15527929 http://dx.doi.org/10.1016/j.appet.2004.06.002

[16] Morley JE. Anoraxia of aging: Physiologic and pathologic. Am J Clin Nutr. 1997; 66: 760-73. PMid:9322549

[17] Visvanathan R. Under-nutrition in older people: A Serious and growing global problem! J Postgrad Med. 2003 ; 49 : $352-60$. PMid:14699239

[18] Macintosh C, Morley JE, Chapman IM. The Anorexia of Ageing. Nutrition. 2000; 983-95. http://dx.doi.org/10.1016/S0899-9007(00)00405-6

[19] Lou M-F, Dai YT, Huang, G-S, Yu P-J. Nutritional status and health outcomes for older people with dementia living in institutions. JAN. 2007; 60(5): 470-477. PMid:17973710 http://dx.doi.org/10.1111/j.1365-2648.2007.04442.x

[20] Lorefält B, Wilhelmsson S. A multifaceted intervention model can give a lasting improvements of older peoples' nutritional status. The Journal of Nutrition, Health \& Aging. 2012; 16(4):378-82. http://dx.doi.org/10.1007/s12603-011-0362-4

[21] Beck AM, Ovesen L. Skipping of meals has a significant impact on dietary intake and nutritional status of old (65+y) nursing home residents. J Nutr Health Aging. 2004; 8: 390-394. PMid:15359358

[22] Laugue S, Arnaud-Battandier F, Gillette S, Plaze J-M, Andrieu S, Cantet C, et al. Improvement of weight and fat-free mass with oral nutritional supplementation in patints with Alzheimer's disease at risk of malnutrition: A prospective randomized study. Journal of American Geriatr Soc. 2004; 52: 1702-7. PMid:15450048 http://dx.doi.org/10.1111/j.1532-5415.2004.52464.x

[23] Wikby K, Ek A-C, Christensson L. Implementation of a nutritional programme in elderly people admitted to resident homes. Scand J Caring Sci. 2009; 23: 421-30. PMid:19170960 http://dx.doi.org/10.1111/j.1471-6712.2008.00632.x

[24] Young KWH, Greenwood CE, van Reekum R, Binns MA. Providing nutrition supplemets to institutionalised seniors with probable Alzheimer's disease is least beneficial to those with low body weight status. J Am Geriatr Soc. 2004; 52: $1305-12$. PMid:15271118 http://dx.doi.org/10.1111/j.1532-5415.2004.52360.x 
[25] Milne AC, Potter J, Vivanti A, Avenell A. Protein and energy supplementation in elderly people at risk from malnutrition. Cochrane Database of Systematic Reviews. 2009. PMid:19370584 http://dx.doi.org/10.1002/14651858.CD003288.pub3

[26] Nijs KA, de Graaf C, Kok FJ, van Staveren WA. Effect of family style mealtimes on quality of life, physical performance, and body weight of nursing home residents: cluster randomised controlled trial. BMJ. 2006; 332: 1180-1184. PMid:16679331 http://dx.doi.org/10.1136/bmj.38825.401181.7C

[27] Pedersen P U. Nutritional care - the effectiveness of active involving elder patients. Journal of Clinical Nursing. 2005; 14: 247-255. PMid:15669934 http://dx.doi.org/10.1111/j.1365-2702.2004.00874.x

[28] Simmons SF, Schnelle JF. Individualized feeding assistance care for nursing home residents: Staffing requirements to implement two interventions. Journal of Gerontology. 2004; 59A(9): 966-73. http://dx.doi.org/10.1093/gerona/59.9.M966

[29] Nieuwenhuizen WF, Weenen H, Rigby P, Hetherington MM. Older adults and patients in need of nutritional support: Review of current treatment options and factors influencing nutritional intake. Clinical Nutrition. 2010; 29: 160-9. PMid:19828215 http://dx.doi.org/10.1016/j.clnu.2009.09.003

[30] Lapane KL, Resnik L. Obesity in nursing homes: An escalating problem. Journal of American Geriatr Soc. 2005; 53: 1386-91. PMid:16078966 http://dx.doi.org/10.1111/j.1532-5415.2005.53420.x

[31] Rubenstein LZ, Harker JO, Salva A, Guigoz Y, Vellas BJ. Screening for undernutrition in geriatric practice: developing the short-form mini-nutritional assessment (MNA-SF). J Gerontol A Biol Sci Med Sci. 2001; 56: M366-M372. PMid:11382797 http://dx.doi.org/10.1093/gerona/56.6.M366

[32] Sørensen LB, Møller P, Flint A, Martens M, Raben A. Effect of sensory perception of foods on appetite and food intake: a review of studies on humans. Int J Obes Relat Metab Disord. 2003; 27: 1152-66. PMid:14513063 http://dx.doi.org/10.1038/sj.ijo.0802391

[33] Bourdel-Marchasson I, Rolland C, Jutand M-A, Egea C, Baratchart B \& Barger-Gateau P. Undernutrition in geriatric institutions in South-West France:Policies and risk factors. Nutrition. 2009; 25: 155-164. PMid:18848433 http://dx.doi.org/10.1016/j.nut.2008.07.016

[34] Aselage MB, Amella EJ. An evolutionary analysis of mealtime difficulties in older adults with dementia. Journal of Clinical Nursing. 2010; 19: 33-41. PMid:20500242 http://dx.doi.org/10.1111/j.1365-2702.2009.02969.x

[35] Lin L-C, Watson R, Wu S-C. What is associated with low food intake in older people with dementia? Journal of Clinical Nursing. 2010; 19: 53-9. PMid:20500244 http://dx.doi.org/10.1111/j.1365-2702.2009.02962.x

[36] Chang C-C, Roberts BL. Feeding diffculty in older adults with dementia. Journal of Clinical Nursing. 2008 ; 17: $2266-74$. PMid:18705703 http://dx.doi.org/10.1111/j.1365-2702.2007.02275.x

[37] Simmons SF, Keeler E, Zhuo X, Hickey KA, Sato H, Schnelle JE. Prevention of unintentional weight loss in nursing home residents: A controlled trial of feeding assistance. J Am Geriatr Soc. 2008; 56: 1466-73. PMid:18637983 http://dx.doi.org/10.1111/j.1532-5415.2008.01801.x

[38] Simmons SF, Osterwell D, Schnelle JF. Improving food intake in nursing home residents with feeding assisstance: A staffing analysis. Journal of Gerontology. 2001; 56A(12): M790-M974.

[39] Polit DF, Hungler BP. Nursing research - Principles and methods. 3rd ed. London: J.B. Lippincott Company, 1987. http://dx.doi.org/10.1093/gerona/56.12.M790 